Article

\title{
Making Green Work: Implementation Strategies in a New Generation of Urban Forests
}

\author{
Víctor Muñoz Sanz ${ }^{1, *}$, Sara Romero Muñoz ${ }^{2}$, Teresa Sánchez Chaparro ${ }^{2}$, Lorena Bello Gómez ${ }^{3}$, \\ and Tanja Herdt ${ }^{1}$ \\ ${ }^{1}$ Department of Urbanism, Delft University of Technology, The Netherlands \\ 2 Innovation and Technology for Human Development Centre, Universidad Politécnica de Madrid, Spain \\ ${ }^{3}$ Graduate School of Design, Harvard University, USA \\ * Corresponding author (v.munozsanz@tudelft.nl)
}

Submitted: 30 October 2021 | Accepted: 4 January 2022 | Published: 31 May 2022

\begin{abstract}
The concept of "urban forest" (UF) is gaining momentum in urban planning in the context of climate adaptation. Principles from the field of urban forestry are mainstreamed into urban planning, but little is known about effective tools for the successful implementation of new UFs. This article presents explorative research comparing how three cities (Almere, Madrid, and Boston) are dealing with the planning of a UF project, and their alignment with distinct organisational and typological interpretations of a UF. We employed a mixed-methods approach to gain insights into the main goals of the project, their organisational structure, and the employed planning process through the analysis of project documents and expert interviews. Our results point to an effective mainstreaming of environmental questions among stakeholders, but also indicate a poor development of objective criteria for the success of a UF. We note that municipal planners circumvented current internal rigidities and barriers by relying on intermediaries and local academia as providers of external knowledge, or by facilitating experiments. Finally, our results show that there may not be just one UF type to achieve the desired environmental and social goals and overcome implementation barriers. Conversely, each of the governance and organisational models behind the implementation of each type present collaborative and mainstreaming challenges. Therefore, we see an opportunity in further research examining processes and institutions towards the collaborative building of UFs that could bridge gaps between top-down and bottom-up approaches and activate different types of agencies.
\end{abstract}

\section{Keywords}

climate adaptation; mainstreaming; planning process; urban forestry; urban greening

\section{Issue}

This article is part of the issue "From Smart Urban Forests to Edible Cities: New Approaches in Urban Planning and Design" edited by Alessio Russo (University of Gloucestershire) and Francisco J. Escobedo (USDA Forest Service).

(C) 2022 by the author(s); licensee Cogitatio (Lisbon, Portugal). This article is licensed under a Creative Commons Attribution 4.0 International License (CC BY).

\section{Introduction}

Greening is a mainstream strategy in urban climate policies, and planting trees is particularly popular: Trees capture carbon dioxide, mitigate the urban heat island, and improve liveability and public health. Specifically, the concept of "urban forest" (UF) is gaining momentum in urban planning as a way to protect and expand the urban tree canopy in the context of urban climate adap- tation. Additionally, there is growing political demand to implement tree-planting projects that deploy social and economic co-benefits. Amidst the Covid-19 pandemic, urban greening has been proposed by the US and the European Commission to push economic recovery (European Commission, 2020; The White House, 2021). In this regard, the European Green Deal asks European cities with over 20,000 inhabitants to develop "urban greening plans" by 2030 . 
Cities in Europe and the US are developing comprehensive plans for tree planting. However, little is known about effective approaches to successfully implement new UFs. Despite growing interest and advice to mainstream climate mitigation/adaptation - that is, to make it central to urban policies and programmes-greening is not integral to urban development administrations yet. Principles from the field of urban forestry are adapted to urban planning, yet they do not seem to match current processes of implementation (Ottisch \& Krott, 2005). Furthermore, the decision-making of municipal managers is poorly understood by urban forestry (Ordóñez et al., 2019; Young, 2013). This article addresses those gaps by presenting exploratory research on different implementation strategies for UFs. Specifically, it compares how three cities are dealing with the planning of a UF, and how this aligns with distinct organisational models and typological interpretations of a forest.

Our research has three objectives concerning the main goals of the projects, the nature of their planning processes, and the organisational structures and implementation strategies being taken into consideration. Firstly, understanding how the case for green is made by different stakeholders and their definition of the task of creating a UF. Secondly, examining how municipal planning actors organise and seek support towards overcoming barriers for implementation. Third, ascertaining how and why an implementation strategy, governance, and organisational model is favoured, and the resulting type of UF. To do so, we compare three very different projects under development in three planning systems, belonging to a new generation of UFs: Utopiaeiland in Almere (the Netherlands), the Metropolitan Forest of Madrid (Spain), and the Urban Forest Plan of the City of Boston (US). Our study is explorative and descriptive. We followed a multiple-case study approach with multiple sources of information, combining expert interviews with a study of literature on UFs and mainstreaming, and desk research of planning and project documents accessed through project stakeholders. In opting for a sample of three polar types, we aimed to explore the diversity of approaches to UF at play in cities today.

The article is structured as follows. We begin by positioning the research in the urban planning-UFs nexus in the key urban forestry literature, framing it within the problematics of mainstreaming. Then we explain our methodology and describe the three case studies. Subsequently, we proceed to our analysis of the empirical materials along six dimensions related to our research aims: goals and ambitions, criteria for success, perceived challenges, leverages, implementation strategies, and organisational form. Our results suggest an effective mainstreaming of environmental questions among stakeholders yet indicate a poor development of objective criteria for the success of a UF. We note that municipal planners circumvented current internal rigidities and barriers by relying on intermediaries and local academia as providers of external knowledge, or by facilitating inno- vations in management or procurement. We conclude that there is not just one UF type to achieve the desired environmental and social goals and overcome implementation barriers. Conversely, each of the governance and organisational models behind the implementation of each UF presents collaborative and mainstreaming challenges. In this sense, we see an opportunity in further research examining processes and institutions towards the collaborative building of UFs that could bridge gaps between top-down and bottom-up approaches and activate different types of agencies. The relevance of our contribution is twofold: From a theoretical perspective, it identifies key cultural and organisational elements impacting the process of designing and implementing a UF. From the perspective of planning practice, our research defines possible approaches that cities could adopt to move forward their greening plans.

\section{Mainstreaming Urban Forests Into Urban Planning}

As media theorist Marshall McLuhan reportedly noted, in joining two antagonistic concepts, the term UF radically questions the historic relation between nature and humans (Dean, 2009). In research and policy, a UF is generally considered as the system encompassing all trees within an urban area, and urban forestry as the discipline that deals with their cultivation and management (Carreiro, 2007; Food and Agriculture Organization of the United Nations, 2016; Konijnendijk et al., 2006; Randrup et al., 2005). Although this definition is subject to national and typological interpretations, at its core, a UF has as much to do with forestry as with the urban condition (Randrup et al., 2005).

Therefore, it is mainly municipal urban planning that faces dilemmas and struggles when adjusting processes and strategies to mandates towards mainstreaming tree planting and urban greening (1t.org, 2020; European Commission, 2021). This is clear, for example, in how responsibilities for urban greening are laid in the Biodiversity Strategy of the European Green Deal, specifically at the municipal level (European Commission, 2020). Thus, in this section, we provide an overview from key literature on urban forestry of how the nexus between urban planning and UFs has been addressed, framing it within known challenges of mainstreaming climate change and environmental concerns.

Mainstreaming is a concept created by development agencies to describe a strategy that makes a theme central in the design, implementation, monitoring, and evaluation of policies and programmes of development aid (Gupta, 2010; OECD, 2014). Mainstreaming was first used for gender equality, but eventually reached governance, human rights, disability, and, more recently, climate adaptation and environmental concerns. In this regard, mainstreaming climate change and environmental questions aims to avoid climate policy disintegration across sectoral programmes and projects through multi-actor decision-making processes. 
Consequently, this approach requires profound structural and behavioural change within governance structures (Gupta, 2010; Scott, 2019). Gupta (2010) argued the strength of mainstreaming is that it implies redesigning policies and planning processes, as well as fostering innovation in multi-stakeholder settings. Others criticise mainstreaming tendency to become a top-down, unidirectional process, dismissive of the rationales of other domains, and highly driven by leadership. Critically, such governance spaces are already cluttered with competing norms and interests (Karlsson-Vinkhuyzen et al., 2014; Karlsson-Vinkhuyzen \& Kok, 2011).

Literature on UFs has focused overwhelmingly on operational aspects and on the multiple values of trees, but little on how the implementation of UFs fits within urban planning processes. Elaborations on the multi-functionality of UFs and their benefits have expanded to address the functions, services, disservices, and benefits of green (Cariñanos et al., 2017; McBride, 2017; Pearlmutter et al., 2017; Tyrväinen et al., 2005). Studies have argued that massive urban reforestation could impact global climate adaptation, and advance sustainable development goals (de la Sota et al., 2019; Endreny, 2018; Food and Agriculture Organization of the United Nations, 2016; Teo et al., 2021). Furthermore, efforts have been made to quantify the economic value of urban trees (Antonenko et al., 2020; Rogers et al., $2015,2017)$. Advocates of urban forestry have proposed additional planning principles and methods for mainstreaming UFs into urban planning (Cities4Forests, 2019; Davies et al., 2017; Food and Agriculture Organization of the United Nations, 2016; Schwab, 2019). Specifically, emphasis across this literature is given to six aspects: (1) address the UF in urban plans through measures to protect and manage trees; (2) consider the long-term maintenance of the UF; (3) ensure interdisciplinarity and coherence across plans and departments; (4) form multi-stakeholder collaborations; (5) create feedback mechanisms to monitor tree data; and (6) shift into an adaptive management approach.

Despite this, urban planning and urban forestry have apparently not been successfully aligned. While the latter has emphasised technical matters, municipal actors value public functions and human well-being more (Barron et al., 2016). Ottisch and Krott (2005, p. 141) concluded that "urban planning as a whole is a very weak partner for urban forestry," given financial restrictions and powerful interests in urban development. Ordóñez et al. (2019) and Young (2013), conversely, disclosed how the decision-making of municipal managers is poorly understood by urban forestry experts. In particular, how those municipal employees find support to implement their decisions through new governance arrangements. These processes would benefit from stronger coordination models and a better understanding of how competing problems are prioritised (Ordóñez et al., 2020).

Therefore, despite growing appeals to support mainstreaming concerning climate mitigation/adaptation, a gap in project implementation persists within municipal practices. Conflicting interests and the lack of information, guidance, funding, and coordination between municipal departments are the most prominent barriers identified (Mogelgaard et al., 2018; Runhaar et al., 2018; Zuniga-Teran et al., 2020). The risks of such a gap in daily urban management tasks are that mainstreaming may turn out to be ceremonial, or that the new focus undermines other agendas, creating winners and losers (Bulkeley, 2013; Gupta, 2010; Karlsson-Vinkhuyzen \& Kok, 2011).

Literature suggests that there is a need for empirical information on the frictions between strategies for mainstreaming UFs in urban planning and the messy reality of urban governance. It is still unclear what purpose a UF serves for different urban stakeholders; how barriers, leverages to implementation, and the embeddedness in a specific urban planning and urban forestry culture condition the planning process and the type of UF which is chosen; and how models of UF governance position within the classic top-down vs. bottom-up dichotomy (Ferguson \& Gupta, 2002; Smith, 2014), and the nature of the collaborative challenges that emerge in each organisational approach. Understanding implementation processes and related organisational models is relevant to both urban planning and urban forestry. Firstly, as Förster (2014) noted, the results of planning methods and their contribution to the success of a planning process are rarely observed. This is critical as planning principles and methods are often decoupled from planning practice (Carlsson-Kanyama et al., 2008; Janssen et al., 2006; Nye \& Rydin, 2008; Vervoort et al., 2010; Walker et al., 2008). Second, it emphasises UF as an oxymoron and contributes to advancing its understanding as a political arena in need of reconceptualization to better fit in the urban (Macnaghten, 2003; Perkins, 2014; Purdon, 2003; Sandberg et al., 2014).

To fill this gap, we adopted a multiple-case study approach to conduct exploratory research and compare three UF plans from three different cities and planning systems. These cases typify distinct approaches to implementation of an UF, and thus can be considered as extreme or polar types-cases of particular research interest in which the phenomenon under study is transparently observable (Pettigrew, 1990). This research has both theoretical and practical implications. From a theoretical point of view, it identifies key elements related to the process of designing and implementing a UF. From a practical point of view, our research can offer an overview of potential paths forward that could be used by municipalities willing to implement future plans.

\section{Methodology and Case Studies}

\subsection{Methodology}

This research follows a multiple-case study methodology, based on the analysis of a variety of data sources that 
offer rich empirical descriptions of specific instances of a contemporary phenomenon, "the case" (Yin, 1981). Case studies enable insights into complex relationships that can provide useful pointers for addressing major substantive themes in a field (Yin, 1992) and are also useful for theory building (Eisenhardt, 1989). Over the last decades, case studies have been used extensively in multiple fields, including organisational theory (Galunic \& Eisenhardt, 2001), strategy and decision science (Zelikow \& Allison, 1999), and, most importantly for this work, sustainability (Assefa \& Frostell, 2007; Dwyer et al., 2009; Moreno-Serna et al., 2020). In particular, case studies have been used in works that explore different aspects of urban transformation around sustainability (Ernst et al., 2016; Hölscher et al., 2019).

Our sources of information for the description and analysis of the case studies were planning and project documents, and expert interviews with urban stakeholders with essential roles in the projects investigated. Project documents of each case were used to get an idea about the official project goals, its size, and general aspects of its organisation. The documents were accessed through the interviewed stakeholders and project-related websites. These included tendering documents, zoning plans, project presentations, and news items, among others. The analysis focused in each case on understanding the use of the UF as an instrument for a particular purpose; the planning process, project set-up, and actors; the quality of the development and implementation process; the quality of the project's organisational structure (namely the functions of actors involved and their impact in the implementation process); and the embeddedness of the UF in a specific urban planning and urban forestry culture.

Expert interviews were central to our project analysis. By experts, we mean persons possessing institutionalised authority and knowledge with the potential of conditioning the actions of others in a meaningful way (Meuser \& Nagel, 2009). Therefore, expert interviews facilitate gaining insights and context knowledge central to the research question that cannot be deduced from the literature (Mieg \& Näf, 2006). Our sample consisted of municipal managers, academic partners, designers, and representatives of the third sector (i.e., NGOs) with long-term experience in each project identified during our preliminary research. We conducted semi-structured interviews with three experts within each project, always including a municipal manager. We relied on a fixed questionnaire for each interview, allowing comparison and maintaining data quality. The questions touched upon six dimensions: goals and ambitions, criteria for success, perceived challenges, leverages, implementation strategies, and organisational form. A qualitative analysis of the transcripts was conducted, allowing us to identify meaningful themes and sub-themes within each dimension, contributing to a better understanding of each case and the gaps, organisational hurdles, and leverages concerning the mainstreaming of urban forestry into urban planning. The results of the analysis are presented for every dimension, including an elaboration on the themes and subthemes, with figures and illustrative examples.

\subsection{Case Studies}

Our target population was cities engaged in the development of UFs at the time of writing. The analysed sample consisted of three cases and constitutes a "theoretical sample" (Eisenhardt, 1989) including a diversity of elements related to the framework of analysis. In particular, we selected the cases considering different governance models, namely Madrid (top-down initiative both in conception and in implementation); Boston (intermediate: initiative and concept by the top but with a need to collaborate with actors at the bottom); and Almere (bottom-up initiative in conception and in implementation). Furthermore, we included three additional criteria. First, we chose projects in the process of planning or early implementation. With that, we aimed to emphasise a new generation of UFs, born in a different context to that of the emergence of urban forestry in the 1960s. Despite their portrayal as "forests," each of the projects highlights a distinct UF typology, scale, and planning approach. Second, in each context, the discipline of urban forestry has a different status. Third, they are embedded in three different planning systems, yet municipalities are ultimately responsible for the implementation, management, and maintenance of urban green. With that, we want to emphasise the key role of municipalities in assuming the implementation of UFs and address possible gaps in municipal capacity weakening policies.

\subsubsection{Urban Planning System and Presence of Urban Forestry in the National Context of the Case Studies}

The case studies belong to different planning systems. Spanish planning can be characterised as hierarchical. Three levels of government are involved in the design and implementation of urban policies, under the principle of subsidiarity. There are no regional urban development plans, therefore municipalities are responsible for urban planning. In the Dutch case, the project is embedded in a decentralised and plan-led system. Due to the lack of funding, the Dutch government depends on lower levels of government and high levels of policy coordination for the implementation of planning policies. Finally, the American planning system is decentralised and fiscally driven. Municipalities need to be economically autonomous. This promotes the use of property tax by land use, favouring economic development.

The consideration of urban forestry in urban planning is uneven across the case studies. Urban forestry reached the Netherlands early, with researchers promoting the concept in 1984 (Randrup et al., 2005). Dutch urban forestry builds on a tradition exemplified by the Amsterdamse Bos, a UF considering open-ended 
successional processes (Berrizbeitia, 2007). Several cities in Spain have developed projects of green infrastructure (de las Rivas Sanz \& Fernández-Maroto, 2019), but, generally, the focus on urban trees has centred on their ornamental value. In fact, the first Spanish master's programme in urban forestry began only in 2019. With a 200-year long history of management of urban trees, the US is the birthplace of urban forestry, even before its "invention" (Jones, 2017; Konijnendijk et al., 2006).

\subsubsection{Utopiaeiland Food-Forest, Almere}

Utopiaeiland is an agroforestry project (1.4 ha) located on municipal land adjacent to the horticultural exhibition Floriade 2022. Initially, the municipality assigned the forested island to several entrepreneurs as an incubator of green start-ups with poor results. Instead, the Weerwoud Foundation was granted permission to transform the existing forest into a pilot of agroforestry systems with perennials, including horticulture, strip cultivation, and livestock with trees. Additionally, the project involved measures of ecosystem restoration, as well as areas for leisure and education.

The project involves multi-stakeholder cooperation. Weerwoud manages the land under a maintenance contract with the municipality until the end of Floriade, with a possible extension until 2032. The foundation manages volunteers that support maintenance. The project received funds from the national government, Floriade, and Flevocampus-an educational initiative-as it addresses key national environmental concerns around food systems. Local universities of applied sciences use Utopiaeiland for studies and internships. Wageningen University contributes with research to assess the project. Several NGOs are also involved, and entrepreneurs are exploring the commercialisation of locally grown products.

\subsubsection{Metropolitan Forest of Madrid}

The Metropolitan Forest of Madrid is a planned 75-kilometre-long forest belt, promoted by the Madrid City Council. Its total area will be 32.035 ha, of which $81 \%$ are existing natural spaces. Two million trees are projected to be planted in the coming 10 years in 2.300 ha of residual peripheral land, $50 \%$ of it in private ownership. It aims to mitigate the urban heat island, improve air quality, prevent desertification, support biodiversity, promote social cohesion, and increase the quality of life. The project is embedded in the municipal plan "Madrid 360," intended for meeting emission limits imposed by the European Commission. It is important to pinpoint that Madrid developed a roadmap for decarbonisation in 2050, a long-term strategy aimed at making climate adaptation initiatives more resilient to changes in political will. Another strategy in that same direction has been to adhere to Climate-KIC's Deep Demonstration of Healthy and Clean Cities initiative and to CitiES2030, a network of four Spanish cities to accelerate action towards climate neutrality.

For contracting the design and production information development phase of the UF, Madrid City Council prepared a public tender, distributing the forest in five lots. To broaden the diversity of agents involved in the planning project, the City Council team and its academic partner (Universidad Politécnica de Madrid) concurred with experimenting with public procurement. The outcome was a series of participatory sessions, involving more than 800 people from municipal bodies, citizen groups, private companies, NGOs, and academia. This process delivered criteria for the five temporary consortiums of companies that won the tender, based on an extended meaning of what kind of forest Madrid wanted.

\subsubsection{Urban Forest Plan of Boston}

The Urban Forest Plan of Boston is an initiative of the city's Parks and Recreation Department. As a result of a public tender, Stoss Landscape Urbanism and Urban Canopy Works act as its lead consulting firms. The plan understands the UF as a generator of resilience and equity for all citizens. Through increasing street trees in the lowest-income neighbourhoods, Boston intends to address the unequal relationship between income and tree canopy, ameliorate the heat island effect, and improve air quality for its neediest citizens first.

The plan is strategic given that Boston has little land for tree planting besides its streets. The citywide and regional park system developed by Frederick Law Olmsted and Charles Eliot provides the starting point for the UF. Additionally, low-density neighbourhoods and universities with many privately-owned trees and wide streets are operationalized for conserving tree canopy. The goal is for the plan to be based on science, data-driven, and defined by the needs and desires of the community. It emphasises maintenance and public engagement, as the city wants to ensure better management today and 20 years from now.

\section{Results}

\subsection{Goals and Ambitions}

The most important arguments cited as goals and ambitions for the UFs by all actors were related to environmental, social, and economic sustainability. These revolved around three dimensions: First, to develop environmental awareness and engagement, exploring forms of participatory design and management. Particularly interesting were ambitions concerning environmental and community education specifically dealing with training communities to maintain and expand the UF in both Almere and Boston, or be more engaged in food production, in Almere. Second, the provision of environmental benefits to address relevant urgencies in each context (ecosystem restoration, water management). Third, to 
increase the environmental qualities of the surrounding areas, having an impact on communities and their health and access to urban green (specifically climate justice in the Boston case). Innovation in both management and maintenance was mentioned mainly by municipal actors in the three cases: on the one hand, concerning elaborating legal frameworks to guarantee consistent management in the long term; on the other, connected to developing evidence-based approaches to maintenance that could inform or transform current municipal practises.

\subsection{Criteria for Success}

Criteria for success stated during the interviews were qualitative, not attached to specific benchmarks. For all municipal actors, their project would be successful if it was able to generate science-backed insights or mechanisms on how to combine environment criteria with social needs and landscape quality with economic viability for ongoing maintenance. Thus, success for this group is mainly related to having enough monetary resources or finding the right framework to implement their measures. In particular, it was considered a measure of success if a project was able to develop clear, innovative, and easily enforceable policies and ordinances to bring on board the private sector and other municipal departments in the implementation of a UF vision. Representatives of the third sector and knowledge institutions emphasised having an impact on increased environmental awareness and education as the desired accomplishment of the project. Common ground between both criteria is found in seeing success if the projects activate local communities for co-management and upscaling.

\subsection{Perceived Challenges}

How the internal coordination, frictions, and interests within municipal departments may affect the development and management of the UF projects is a critical barrier to implementation. This is a shared concern among stakeholders, including those working in municipal departments. Specific problems are: differences in approach between departments on urban green management (tree ordinances tend to focus on technical and operational aspects and not on ecological ones); existing institutional inertias, with innovation hindered by business as usual; lack of consistency and continuity of municipal actors and budget through political cycles (with funding focusing on capital and tree planting, and not in long-term maintenance); problems with staff resources (understaffing, lack of qualified personnel, or dependence on volunteers); and political overemphasis on quick impact through tree planting.

This suggests that a lack of strong vision and leadership is highly detrimental to successful implementation. However, representatives of the third sector and knowledge institutions indicated an excessive depen- dence on personal leadership as a barrier, as it risks damaging long-term prospects of continuity. For municipal actors, another important challenge was dealing with private property in the domain of their project. Negotiating transfers of land or co-management responsibilities were noted as complicated in the face of interests in urban development.

\subsection{Leverages: How Municipal Actors Find Support}

Municipal actors involved in the UFs of study search for support and legitimation mainly in knowledge external to their organisation. First, by involving knowledge institutions as stakeholders. These were considered of interest as they can contribute to the scientific validation of innovative management and maintenance strategies, increasing environmental awareness through educational activities and facilitating boundary-spanning collaborations, continuity, and trust-building in complex multi-actor settings. Second, by operationalizing knowledge from recognized best practices in climate mitigation. Third, by seeking innovative approaches in the design, management, and maintenance of UFs from other parties, namely citizens, NGOs, or consulting design firms. Cities also find support in national and international agendas. In the case of Madrid, being one of the 15 European cities part of the EIT Climate-KIC Deep Demonstration programme has enabled the continuity of the multi-actor collaboration despite the political change in the city council government.

The development of pilots or demonstration projects, as in the case of Almere, is a related strategy mentioned by municipal actors for gaining knowledge and support. Pilots would allow for experimentation with limited risks. Finally, growing social and political concerns on climate change are considered leverage to enact action. However, all actors interviewed affirmed that more environmental awareness is needed, hence the importance of involving knowledge institutions and academia in the projects.

\subsection{Governance and Implementation Strategy and Typology of Urban Forest}

Despite the common ground across cases in terms of goals, criteria for success, barriers, and leverages, we observed distinct approaches in how and why a specific governance and implementation strategy and type of UF is favoured (Figure 1). In Almere, the project was initiated from the bottom by an NGO and includes a volunteer training programme. This UF was conceived as a spatially defined, small-scale demonstration landscape. It is aligned with national concerns on sustainable food production, research agendas, and steered by strong personal leadership. The declared perceived role of the municipal actor was simply to facilitate a legal framework, via a maintenance contract. They favoured this UF type as a pilot towards scaling-up innovative urban 


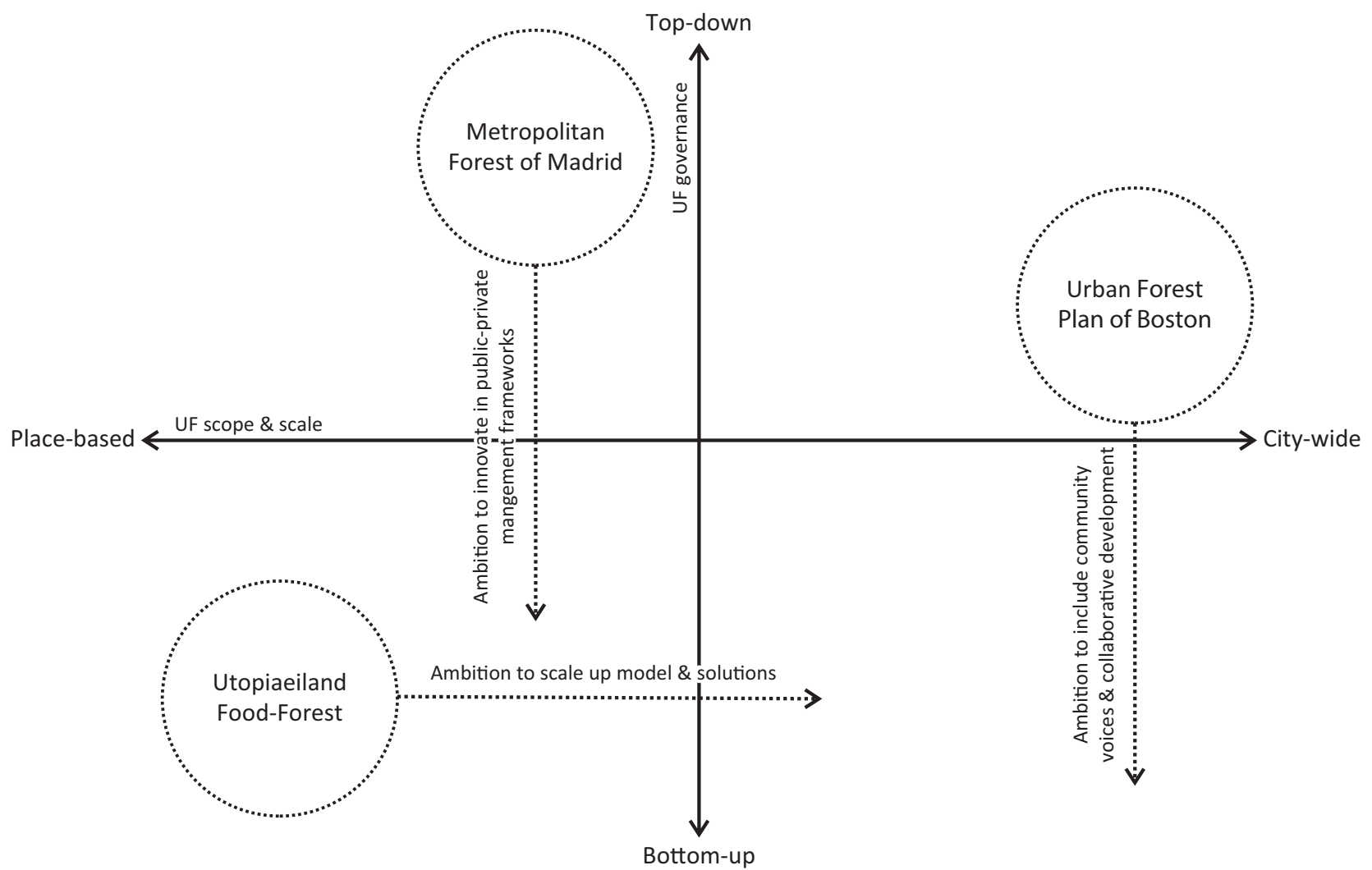

Figure 1. Position and ambition of the case studies within the top-down/bottom-up spectrum and range of scope and scale of the UF project.

green management and maintenance and replacing current municipal practices.

In Madrid, the project is managed by the DirectorateGeneral for Strategic Planning, part of the Urban Development Government Area of the Madrid City Council. The typology of the UF as a municipally funded place-bound strategic project was chosen over a plan of urban forestry encompassing the whole city. The planning figure of a master plan was indicated as the preferred one. A new legal figure of land custody was mentioned to reach agreements with private owners for comanagement. In implementing a master plan, municipal planners stated a desire to set a long-term legal framework for the UF, and to organise its maintenance differently than in other green areas of the city. Legitimation for this top-down approach was addressed through a collaborative, university-led multi-stakeholder process aimed at informing a process of public tendering, and through the adherence to (inter)national programmes.

In Boston, providing equal access to tree canopy coverage and related environmental benefits and qualities was declared as pivotal in the choice of the UF project. To maximise impact, this project follows the canonical definition of UF as a municipally led strategy dealing with all trees within the city. Given its wide scope, coordination and collaboration with multiple urban stakeholders to ensure legitimacy and sustainability are considered of critical importance in the interviews. Specifically, the municipal informant mentioned the goal of involv- ing local communities in the planning process and future management of the UF, including plans for a workforce training programme. It is also desired that guidelines for city and private landowners can be easily followed and enforced.

\subsection{Organisational Form of the Case Studies: Characterization and Gaps}

Figure 2 presents a characterization of the organisational form of the case studies, showing how each case stands with regard to the project governance (top-down vs. bottom-up) and the distribution of agency (coherent vs. diverse). In the horizontal axis of the diagram, we use "diverse" to characterize actors that are in fact coalitions of agents, each one with a different interest and level of agency; these may be organisations with a horizontal structure, or groups of entities within one same category that do not constitute an organisation per se (businesses, local communities). With "coherent" we refer to actors in which agency is consolidated in one or a few organisational units (e.g., municipal departments). This characterization allows pointing out gaps in the structure of each project. In turn, these gaps direct at possible organisational hurdles impacting both the attainment of declared goals and ambitions and, more generally, the successful mainstreaming of urban forestry in the planning process. Utopiaeiland is a bottom-up project, organised around a wide array of actors. However, its 


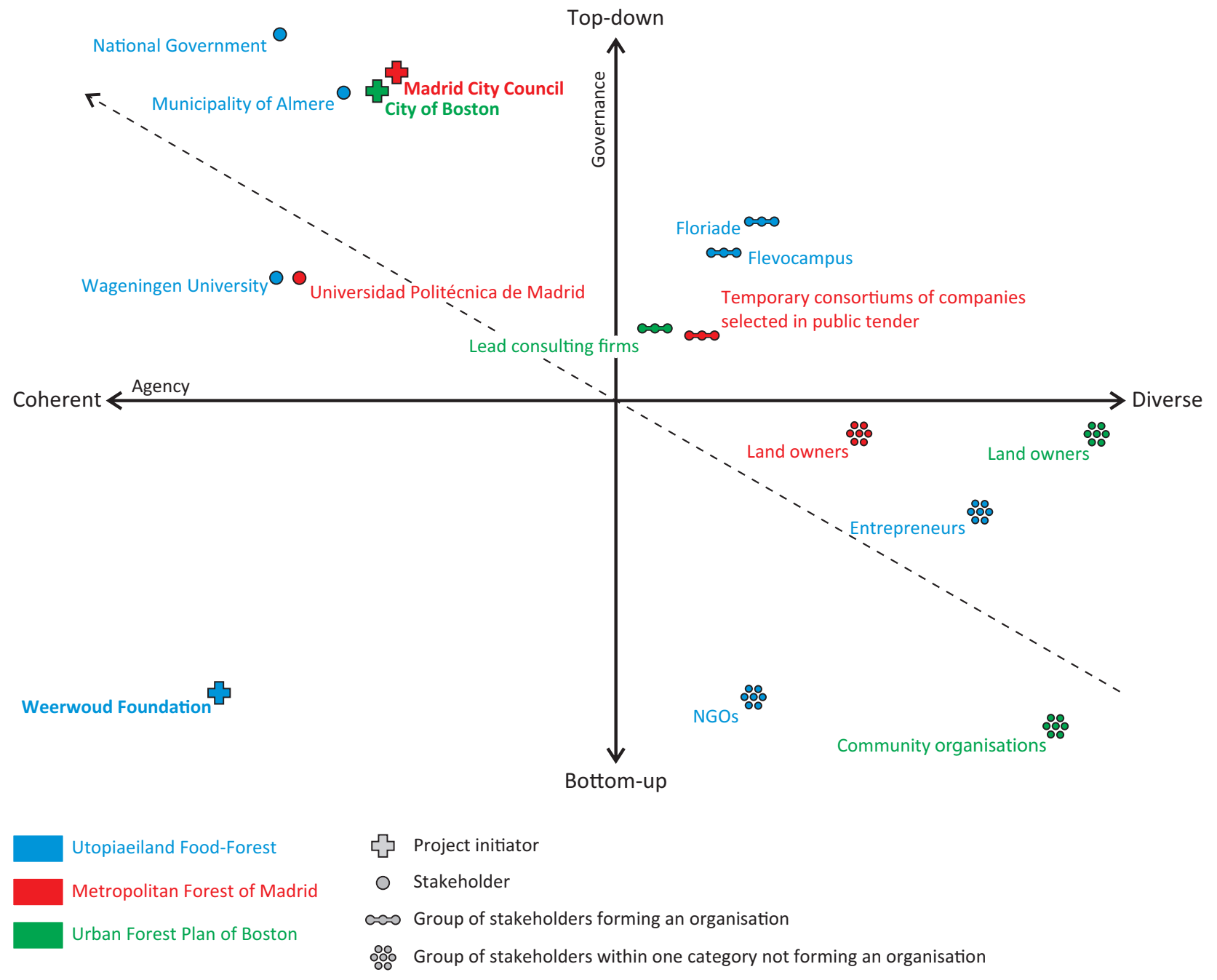

Figure 2. Characterization of the organisational form of the case studies.

implementation is characterized by its dependency on single, coherent, bottom-up leadership, and low levels of involvement of actors at the top. Therefore, such a governance model highlights possible collaborative and continuity challenges, which may affect the mainstreaming and scaling-up of the model. The Metropolitan Forest of Madrid can be characterized not just as top-down, but also as a project mostly organised around a set of very coherent actors with regard to their agency. Such an approach signals a gap in how to address more strongly the involvement of local communities and actors to achieve its goal towards participatory management. The Urban Forest Plan of Boston can be described also as top-down, yet it highlights an intermediate approach, as it gathers diverse actors in a balanced manner. Therefore, such a model places a higher emphasis on setting collaborative structures and routines and responds to a long tradition in urban forestry management.

\section{Discussion and Conclusion}

The results of this study have helped us answer our exploration of the nature of planning processes and imple- mentation strategies being taken into consideration by municipal planners in UF projects. Concerning our first research aim, the results provide insights in understanding how the need for a UF is justified by different stakeholders, and what their definition of success in the task of creating a UF is. These results confirm studies signalling high levels of concern among urban stakeholders for environmental questions, such as ecosystem services (Young, 2013), pointing at an effective mainstreaming of such concepts. However, our results also indicate a poor development of objective criteria for the success of a UF, validating an identified gap in the literature (Ordóñez et al., 2019). A deeper exploration of benchmarks for UF plans could help sharpen municipal strategies and support adaptive management of such projects. The risk here is to focus only on quantitative assessments of tree performance (Mattern, 2021). For that, parameters ought to be holistic, place-specific, and include qualitative dimensions.

Concerning our second research aim, in our case studies, we identified how municipal planners are attempting to circumvent current rigidities and barriers to implementation. Our results indicate that the 
main perceived barriers to UF are not precisely those linked to pressures of urban transformation, but to the lack of information, guidance, funding, continuity, and coordination between municipal departments, confirming insights from environmental mainstreaming literature (Mogelgaard et al., 2018; Runhaar et al., 2018; Zuniga-Teran et al., 2020). These barriers particularly impact long-term management and maintenance. Municipal actors seek support mainly from intermediaries, local academia, and (inter)national agendas to legitimise strategies, receive external knowledge, or coordinate experiments in governance, management, and maintenance.

Finally, and linked to our third research aim, understanding how and why a certain implementation strategy and type of UF is chosen questions the need to follow the usual definition of UF to introduce this concept into our cities. The urban forestry-centred definition of a UF strategy as that dealing with all trees within a city (Konijnendijk et al., 2006; Randrup et al., 2005) demands high levels of coordination and resources. Not all cities count with the technical capacities and planning heritage to immerse in such an endeavour. We note that, despite the importance of multi-stakeholder partnerships, ultimately, with such an approach, most of the responsibilities fall on the shoulders of municipalities. The strength of our results is that they show that considering the spectrum of possible top-down/bottom-up approaches and diversity of contextual conditions reveals that there is not just one UF type to opt for to achieve the desired environmental and social goals and overcome implementation barriers. In this sense, we see an opportunity in further examining processes towards the collaborative building of a context-specific idea of a forest.

There seems to be a dynamic quality in the development of a UF in relation to the top-down/bottom-up and scale and scope dimensions (with Almere wanting to scale up and Madrid and Boston aspiring to activate bottomup actions). With top-down projects tending to have a wider ambition in terms of their spatial scope, further research is needed on the setting up of collaborative structures that might bridge the top-down/bottom-up gap and activate underutilized agencies among urban stakeholders towards sustainable city-wide urban greening. The Madrid Metropolitan Forest is not relying on, for example, local businesses; yet, it may need their involvement for future management and maintenance to be organised locally. While cases like Boston and Almere showcase interesting approaches for collaboration among diverse actors, our results point out gaps and challenges in terms of organisation that may impact success. In that regard, it would be important to corroborate our findings at a later stage of the development of the projects.

All in all, for a better implementation of UFs there is a need to further dive into strategies to strengthen current planning structures and processes or to conceptualise entirely new planning institutions and experimental forms of climate governance (Bulkeley, 2013). The results call for the urgent development of "urban transformative capacities" (Wolfram et al., 2019) towards reinventing urban planning and overcoming existing lock-ins in its processes. There are two major limitations in this study that could be addressed also through future research. First, we focused only on cities in Europe and North America, while including perspectives from other geographies could provide insights on alternative approaches to urban greening. Second, being this an exploratory, qualitative study, we are unable to fully generalise the research findings. Accordingly, a larger sample of case studies and a quantitative approach could provide a richer overview of the ways cities face the challenge of greening.

\section{Acknowledgments}

The authors would like to sincerely thank all urban stakeholders interviewed in Almere, Boston, and Madrid for their time and generosity.

\section{Conflict of Interests}

The authors declare no conflict of interests.

\section{References}

1t.org. (2020). A platform for the trillion tree community. https://www.1t.org

Antonenko, M., Dushkova, D., \& Krasovskaya, T. (2020). Urban forests in megacities from the perspective of ecosystem services using the Timiryazevsky Forest Park, Moscow, as a case study. In J. Breuste, M. Artmann, C. Ioja, \& S. Qureshi (Eds.), Making green cities: Concepts, challenges and practice (pp. 180-193). Springer Nature.

Assefa, G., \& Frostell, B. (2007). Social sustainability and social acceptance in technology assessment: A case study of energy technologies. Technology in Society, 29(1), 63-78.

Barron, S., Sheppard, S. R., \& Condon, P. M. (2016). Urban forest indicators for planning and designing future forests. Forests, 7(9), Article 208.

Berrizbeitia, A. (2007). Re-placing process. In J. Czerniak, G. Hargreaves, \& J. Beardsley (Eds.), Large parks (pp. 175-197). Princeton Architectural Press.

Bulkeley, H. (2013). Climate change and urban governance: A new politics? In S. Lockie, D. A. Sonnenfeld, \& D. R. Fisher (Eds.), Routledge international handbook of social and environmental change ( $\mathrm{pp}$. 173-185). Routledge.

Cariñanos, P., Calaza-Martínez, P., O’Brien, L., \& Calfapietra, C. (2017). The cost of greening: Disservices of urban trees. In D. Pearlmutter, C. Calfapietra, R. Samson, L. O'Brien, S. Krajter Ostoić, G. Sanesi, \& R. Alonso del Amo (Eds.), The urban forest: Cultivating green infrastructure for people and the environment (pp. 79-87). Springer International Publishing.

Carlsson-Kanyama, A., Dreborg, K. H., Moll, H. C., \& 
Padovan, D. (2008). Participative backcasting: A tool for involving stakeholders in local sustainability planning. Futures, 40(1), 34-46.

Carreiro, M. M. (2007). Introduction: The growth of cities and urban forestry. In M. M. Carreiro, Y. C. Song, \& J. Wu (Eds.), Ecology, planning, and management of urban forests: International perspective (pp. 3-9). Springer.

Cities4Forests. (2019). Urban forests for healthier cities: Policy, planning, and institutional arrangements. https://cities4forests.com/wp-content/uploads/ 2020/06/C4F-Urban-Forests-for-Healthier-Cities.pdf

Davies, C., Andreucci, M. B., Zurcher, N., De Vreese, R., Verlič, A., Sanesi, G., Bernasconi, A., \& Calfapietra, C. (2017). Guidelines for urban forestry as critical green infrastructure in European urban areas. European Cooperation in Science and Technology (COST). https://www.panbern.ch/download/pictures/d4/ 18crwqzie49ruweikloq3qmpkiz7hk/davies_et_al._ 2017_guideline.pdf

de la Sota, C., Ruffato-Ferreira, V. J., Ruiz-García, L., \& Alvarez, S. (2019). Urban green infrastructure as a strategy of climate change mitigation. A case study in northern Spain. Urban Forestry \& Urban Greening, 40, 145-151.

de las Rivas Sanz, J. L., \& Fernández-Maroto, M. (2019). Planning strategies for a resilient urban fringe in three medium-sized Spanish cities. Planning Perspectives, 34(4), 725-735.

Dean J. (2009). Seeing trees, thinking forests: Urban forestry at the University of Toronto in the 1960s. In A. Mac Eachern \& W. Turkel (Eds.), Method and meaning in Canadian environmental history (pp. 236-253). Nelson Education.

Dwyer, R., Lamond, D., \& Lee, K.-H. (2009). Why and how to adopt green management into business organizations? Management Decision, 47(7), 1101-1121.

Eisenhardt, K. M. (1989). Building theories from case study research. The Academy of Management Review, 14(4), 532-550.

Endreny, T. A. (2018). Strategically growing the urban forest will improve our world. Nature Communications, 9(1), Article 1160.

Ernst, L., de Graaf-Van Dinther, R. E., Peek, G. J., \& Loorbach, D. A. (2016). Sustainable urban transformation and sustainability transitions; conceptual framework and case study. Journal of Cleaner Production, 112(Part 4), 2988-2999.

European Commission. (2020). Communication from the Commission to the European Parliament, the Council, the European Economic and Social Committee and the Committee of the Regions. EU Biodiversity Strategy for 2030: Bringing nature back into our lives. https://eur-lex.europa.eu/legal-content/EN/TXT/ ?uri=CELEX:52020DC0380

European Commission. (2021). 3 billion trees pledge. https://ec.europa.eu/environment/3-billiontrees_en
Ferguson, J., \& Gupta, A. (2002). Spatializing states: Toward an ethnography of neoliberal governmentality. American Ethnologist, 29(4), 981-1002.

Food and Agriculture Organization of the United Nations. (2016). Guidelines on urban and peri-urban forestry (FAO Forestry Papers No. 178). https://www.fao.org/ policy-support/tools-and-publications/resourcesdetails/es/c/1155338

Förster, A. (2014). Enhancing the effectiveness of spatial planning processes. Impacts, basic building blocks and critical variables of communicative planning methods [Doctoral dissertation, TU Munich]. mediaTUM. https://mediatum.ub.tum.de/1210593

Galunic, D. C., \& Eisenhardt, K. M. (2001). Architectural innovation and modular corporate forms. Academy of Management Journal, 44(6), 1229-1249.

Gupta, J. (2010). Mainstreaming climate change: A theoretical exploration. In N. van der Grijp \& J. Gupta (Eds.), Mainstreaming climate change in development cooperation: Theory, practice and implications for the European Union (pp. 67-96). Cambridge University Press.

Hölscher, K., Frantzeskaki, N., McPhearson, T., \& Loorbach, D. (2019). Tales of transforming cities: Transformative climate governance capacities in New York City, US and Rotterdam, Netherlands. Journal of Environmental Management, 231, 843-857.

Janssen, M. A., Goosen, H., \& Omtzigt, N. (2006). A simple mediation and negotiation support tool for water management in the Netherlands. Landscape and Urban Planning, 78(1), 71-84.

Jones, J. (2017). Urban forests: A natural history of trees and people in the American cityscape. Penguin Books.

Karlsson-Vinkhuyzen, S. I. S. E., Boelee, E., Cools, J., Visseren-Hamakers, I. J., van Hoof, L. J. W., Hospes, O., Kok, M., Peerlings, J. H. M., Podvin, K. J., van Tatenhove, J. P. M., \& Termeer, C. J. A. M. (2014). Mainstreaming biodiversity where it matters most. Public Administration and Policy Group; Wageningen University; PBL Netherlands Environmental Assessment Agency. https://edepot.wur.nl/335490

Karlsson-Vinkhuyzen, S. I. S. E., \& Kok, M. T. J. (2011). Interplay management in the climate, energy, and development nexus. In S. Oberthür \& O. Schram Stokke (Eds.), Managing institutional complexity: Regime interplay and global environmental change (pp. 285-312). MIT Press.

Konijnendijk, C. C., Ricard, R. M., Kenney, A., \& Randrup, T. B. (2006). Defining urban forestry: A comparative perspective of North America and Europe. Urban Forestry \& Urban Greening, 4(3/4), 93-103.

Macnaghten, P. (2003). Embodying the environment in everyday life practices. The Sociological Review, 51(1), 63-84.

Mattern, S. (2021). Tree thinking. Places Journal. https:// doi.org/10.22269/210921

McBride, J. R. (2017). The world's urban forests: His- 
tory, composition, design, function and management. Springer International Publishing.

Meuser, M., \& Nagel, U. (2009). The expert interview and changes in knowledge production. In A. Bogner, B. Littig, \& W. Menz (Eds.), Interviewing experts (pp. 17-42). Palgrave Macmillan.

Mieg, H. A., \& Näf, M. (2006). Experteninterviews in den Umwelt-und Planungswissenschaften: Eine Einführung und Anleitung [Expert interviews in the environmental and planning sciences: An introduction and guide]. Pabst Science Publishers.

Mogelgaard, K., Dinshaw, A., Ginoya, N., Gutiérrez, M., Preethan, P., \& Waslander, J. (2018). From planning to action: Mainstreaming climate change adaptation into development. World Resources Institute. https://www.wri.org/research/planning-actionmainstreaming-climate-change-adaptationdevelopment

Moreno-Serna, J., Sánchez-Chaparro, T., Mazorra, J., Arzamendi, A., Stott, L., \& Mataix, C. (2020). Transformational collaboration for the SDGs: The Alianza Shire's work to provide energy access in refugee camps and host communities. Sustainability, 12(2), Article 539.

Nye, M., \& Rydin, Y. (2008). The contribution of ecological footprinting to planning policy development: Using REAP to evaluate policies for sustainable housing construction. Environment and Planning B: Planning and Design, 35(2), 227-247.

OECD. (2014). Mainstreaming cross-cutting issues: Seven lessons from DAC peer reviews. https://www.oecd. $\mathrm{org} / \mathrm{dac} /$ mainstreaming-cross-cutting-issues9789264205147-en.htm

Ordóñez, C., Threlfall, C. G., Kendal, D., Hochuli, D. F., Davern, M., Fuller, R. A., van der Ree, R., \& Livesley, S. J. (2019). Urban forest governance and decisionmaking: A systematic review and synthesis of the perspectives of municipal managers. Landscape and Urban Planning, 189, 166-180.

Ordóñez, C., Threlfall, C. G., Livesley, S. J., Kendal, D., Fuller, R. A., Davern, M., van der Ree, R., \& Hochuli, D. F. (2020). Decision-making of municipal urban forest managers through the lens of governance. Environmental Science \& Policy, 104, 136-147.

Ottisch, A., \& Krott, M. (2005). Urban forest policy and planning. In C. Konijnendijk, K. Nilsson, T. Randrup, \& J. Schipperijn (Eds.), Urban forests and trees: A reference book (pp. 117-148). Springer.

Pearlmutter, D., Calfapietra, C., Samson, R., O'Brien, L., Ostoić, S. K., Sanesi, G., \& del Amo, R. A. (Eds.). (2017). The urban forest: Cultivating green infrastructure for people and the environment. Springer International Publishing.

Perkins, H. (2014). Urban forests are social natures: Markets, race, class, and gender in relation to (un)just urban environments. In L. A. Sandberg, A. Bardekjian, \& S. Butt (Eds.), Urban forests, trees, and greenspace (pp. 19-34). Routledge.
Pettigrew, A. M. (1990). Longitudinal field research on change: Theory and practice. Organization Science, 1(3), 267-292.

Purdon, M. (2003). The nature of ecosystem management: Postmodernism and plurality in the sustainable management of the boreal forest. Environmental Science \& Policy, 6(4), 377-388.

Randrup, T. B., Konijnendijk, C., Dobbertin, M. K., \& Prüller, R. (2005). The concept of urban forestry in Europe. In C. Konijnendijk, K. Nilsson, T. Randrup, \& J. Schipperijn (Eds.), Urban forests and trees: A reference book (pp. 9-21). Springer.

Rogers, K., Andreucci, M.-B., Jones, N., Japelj, A., \& Vranic, P. (2017). The value of valuing: Recognising the benefits of the urban forest. In D. Pearlmutter, C. Calfapietra, R. Samson, L. O’Brien, S. Krajter Ostoić, G. Sanesi, \& R. A. del Amo (Eds.), The urban forest: Cultivating green infrastructure for people and the environment (pp. 283-299). Springer International Publishing.

Rogers, K., Sarcre, K., Goodenough, J., \& Doick, K. (2015). Valuing London's urban forest: Results of the London i-Tree Eco Project. Treeconomics London.

Runhaar, H., Wilk, B., Persson, Å., Uittenbroek, C., \& Wamsler, C. (2018). Mainstreaming climate adaptation: Taking stock about "what works" from empirical research worldwide. Regional Environmental Change, 18(4), 1201-1210.

Sandberg, L. A., Bardekjian, A., \& Butt, S. (2014). Introduction. In L. A. Sandberg, A. Bardekjian, \& S. Butt (Eds.), Urban forests, trees, and greenspace (pp. 1-16). Routledge.

Schwab, J. (Ed.). (2019). Planning the urban forest. American Planning Association. https://www.planning. org/publications/report/9026879

Scott, A. (2019). Mainstreaming the environment in planning policy and decision making. In S. Davoudi, R. Cowell, I. White, \& H. Blanco (Eds.), The Routledge companion to environmental planning (pp. 420-433). Routledge.

Smith, N. R. (2014). Beyond top-down/bottom-up: Village transformation on China's urban edge. Cities, 41, 209-220.

Teo, H. C., Zeng, Y., Sarira, T. V., Fung, T. K., Zheng, Q., Song, X. P., Chong, K. Y., \& Koh, L. P. (2021). Global urban reforestation can be an important natural climate solution. Environmental Research Letters, 16(3), Article 034059.

The White House. (2021, March 31). Fact sheet: The American Jobs Plan [Press release]. https://www. whitehouse.gov/briefing-room/statementsreleases/2021/03/31/fact-sheet-the-americanjobs-plan

Tyrväinen, L., Pauleit, S., Seeland, K., \& de Vries, S. (2005). Benefits and uses of urban forests and trees. In C. Konijnendijk, K. Nilsson, T. Randrup, \& J. Schipperijn (Eds.), Urban forests and trees: A reference book (pp. 81-114). Springer. 
Vervoort, M., Flap, H., \& Dagevos, J. (2010). The ethnic composition of the neighbourhood and ethnic minorities' social contacts: Three unresolved issues. European Sociological Review, 27(5), 586-605.

Walker, D. H. T., Bourne, L. M., \& Shelley, A. (2008). Influence, stakeholder mapping and visualization. Construction Management and Economics, 26(6), 645-658.

Wolfram, M., Borgström, S., \& Farrelly, M. (2019). Urban transformative capacity: From concept to practice. Ambio, 48(5), 437-448.

Yin, R. K. (1981). The case study as a serious research strategy. Knowledge, 3(1), 97-114.
Yin, R. K. (1992). The case study method as a tool for doing evaluation. Current Sociology, 40(1), 121-137.

Young, R. F. (2013). Mainstreaming urban ecosystem services: A national survey of municipal foresters. Urban Ecosystems, 16, 703-722.

Zelikow, P., \& Allison, G. (1999). Essence of decision: Explaining the Cuban Missile Crisis. Longman.

Zuniga-Teran, A. A., Staddon, C., de Vito, L., Gerlak, A. K., Ward, S., Schoeman, Y., Hart, A., \& Booth, G. (2020). Challenges of mainstreaming green infrastructure in built environment professions. Journal of Environmental Planning and Management, 63(4), 710-732.

\section{About the Authors}

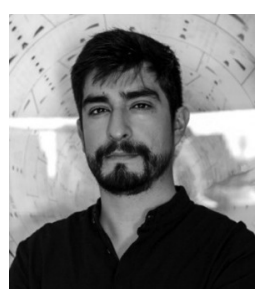

Víctor Muñoz Sanz is an assistant professor of urban design at TU Delft, currently leading research on productive cities and landscapes. Prior to this, he was a postdoctoral researcher at TU Delft, coordinator of the Jaap Bakema Study Centre, and co-principal researcher of "Automated Landscapes" at Het Nieuwe Instituut. Víctor holds the degree of architect from Escuela Técnica Superior de Arquitectura de Madrid, a master's in architecture in urban design from Harvard University, and a PhD cum laude in architecture from Universidad Politécnica de Madrid.

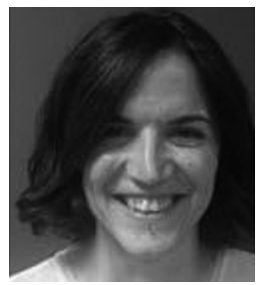

Sara Romero Muñoz is a PhD student at the Universidad Politécnica de Madrid (UPM) researching human behaviour and perceptions on climate change. At the Innovation and Technology for Development Centre (itdUPM), she coordinates projects towards sustainable and equitable urban transformations in multi-actor settings. Sara holds several academic degrees: graduate in social and cultural anthropology, graduate in business sciences, graduate in communication and public relationships, and a master's degree in technology for human development.

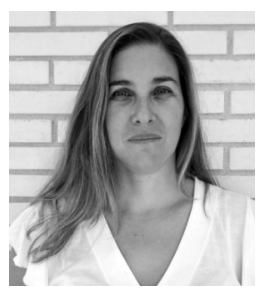

Teresa Sánchez Chaparro is a faculty member at the Department of Industrial Engineering at the Universidad Politécnica de Madrid (UPM). She is academic director at the Innovation and Technology for Development Centre (itdUPM) and member of the Sustainable Organizations research group. Before joining UPM, she held various positions in organisms linked to quality assurance in higher education. Her current research interests are sustainable organisation strategies, sustainable businesses and fourth sector, social marketing, and quality assurance in higher education.

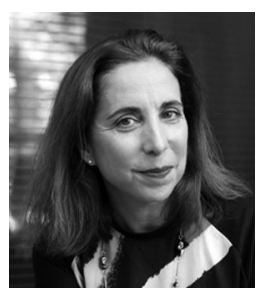

Lorena Bello Gómez is currently a design critic at the Harvard Graduate School of Design (GSD), following her lectureship at MIT from 2013 to 2021. Her current work seeks to connect design and political will to positively impact climatic adaptation. She started examining this topic in her dissertation Hybrid Networks and has applied some of its lessons when working with environmentally vulnerable communities engulfed in climatic risks with her practice TERRALAB. Lorena holds an architecture and urbanism PhD from Barcelona UPC, and a master's in architecture in urban design from GSD.

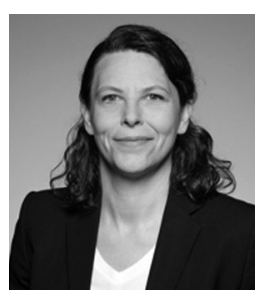

Tanja Herdt is an associate professor of theory and methods of urban design at TU Delft. She is an academic and a practicing urban designer with an emphasis on urban transformation, methods of urban analysis, and history and theory of the city. Tanja received her doctorate from the Department of Architecture at ETH Zurich, where she also was head of research at ETH-CASE. Her book on Cedric Price entitled The City and the Architecture of Change was published by Park Books. 